\section{A Third Factor for Resistance to Puccinia graminis Tritici}

WE have recently found a third factor for resistance to Puccinia graminis Tritici race 34 present in the Kenya varieties of Triticum vulgare, and it is considered that a short statement concerning this would be of interest.

In Australia, varieties of Triticum vulgare from Kenya Colony, East Africa, have been used widely as a source of resistance to $P$. graminis Tritici. Three strains, Kenya 743, 744 and 745 , have been utilized for this purpose. Kenya $743(C 6040)$ is a parent of the commercial variety Eureka developed by the New South Wales Department of Agriculture. Several new rust-resistant lines developed at this University owe their resistance to Kenya 745 ( $C$ 6042). Kenya $744(C 6041)$ was used by wheat breeders in Western Australia since it is also resistant to race 95 of $P$. triticina, which occurs commonly in that State. Although we have used this latter variety, no promising lines have resulted from it.

Varieties of wheat from Kenya Colony have been investigated on the North American continent, and in Canada they have been found to be practically immune to many physiological races of stem rust under some conditions ${ }^{1}$. Since their resistance is much reduced by increasing temperatures they have not proved popular in the spring wheat areas. The effect of high temperatures, $75-80^{\circ} \mathrm{F}$., on the rust reaction of seedlings has also been observed here in the glasshouse but it has never been important on adult plants in the field.

In New South Wales the standard race 34 of $P$. graminis Tritici formed the bulk of the stem rust inoculum until 1941, and all the above varieties were highly resistant to it. Genetical studies have shown that the resistance of each variety is apparently governed by a single major factor. Studies on $F_{3}$ lines have shown that in $\mathbf{7 4 4}$ the factor is the same as that previously recorded for resistance to races 17,36 and 56 and the one in 745 is $K_{1}$, these factors being inherited independently ${ }^{2}$. These two factors are not allelic with the one present in Kenya 743, because when this variety was crossed with 744 and 745 in turn and $\mathrm{F}_{2}$ seedlings were tested with the standard race 34 , it was found that approximately fifteen were resistant and one was susceptible. Although a new rust capable of attacking Kenya 743 has recently turned up in Australia, 744 and 745 remain quite resistant to it. In these latter two varieties it seems that the same gene gives resistance to both the new and the old rusts.

Other varieties which were known to possess a single major gene for resistance to the standard race 34 have been crossed in turn with each of the above three varieties, and on the basis of the segregations of $F_{2}$ and $F_{3}$ seedlings their relationship to them was determined. So far, Kenya 744 is alone in one group but the other two groups are well represented. All varieties which fall into the group with 743 are susceptible to the new rust which attacks this variety, and at the University of Sydney they are all later in maturity than Kenya 745. Included in the 745 group are varieties of Triticum vulgare which have a single factor for resistance and which have derived it from Gaza ( $T$. durum).

While there is clear evidence for the existence of these three independent genes no attempt has been made to allocate symbols to them, since this is at present being undertaken by the committee considering nomenclature of wheat genes.

$$
\text { I. A. Watson. }
$$

W. L. WATERHOUSE.

School of Agriculture,

University of Sydney.

Dec. 20.

${ }^{1}$ Peterson, R. F., Johnson, T., and Newton, M., Science, 91, 313 (1940). ${ }^{2}$ Watson, I. A., Proc. Linn. Soc. N.S.W., 68, 72 (1943).

\section{Nutrients in Wheat Endosperm}

RECENT work $^{1-4}$ has added considerably to our knowledge of the distribution of nutrients, particularly the B vitamins, in the wheat grain. The scutellum portion of the germ is the main deposit of vitamin $B_{1}$, while the bran is rich in nicotinic acid and iron. Riboflavin is more uniformly distributed throughout the grain, although the highest concentrations are found in the germ. Further work has now shown that the endosperm, far from being uniform in composition, has a complex and graded structure.

The endosperm of wheat is bounded by the aleurone layer which is reputedly rich in protein and minerals. In normal milling, however, this aleurone layer, together with an appreciable amount of 'starchy' endosperm, remains firmly attached to the bran. It has long been known that the concentrations of protein and ash increase from the centre to the outer part of the endosperm adjoining the bran or seed coat; $\mathrm{Cobb}^{5}$, for example, found with one sample of wheat that the protein in the central endosperm averaged $7 \cdot 4$ per cent against $16 \cdot 5$ per cent near the periphery. Binnington and Andrews ${ }^{6}$ have also obtained evidence showing that the endosperm adjacent to the bran is much richer in vitamin $\mathrm{E}$ than the endosperm contained in patent flour. It has now been found that there are similar gradients for other nutrients. In one experiment a mixture of English wheats was milled on the laboratory plant to produce a short patent flour. The coarse bran was then freed so far as possible from adhering endosperm by four successive passages through a pair of fluted rolls. These four fractions (sieved finally through a 14 silk :

\begin{tabular}{|c|c|c|c|c|c|c|c|}
\hline \multirow[b]{2}{*}{ Factor } & \multicolumn{4}{|c|}{$\begin{array}{c}\text { Endosperm fractions (corrected for bran } \\
\text { contamination) }\end{array}$} & \multirow{2}{*}{$\begin{array}{l}\text { Cleaned } \\
\text { bran }\end{array}$} & \multirow{2}{*}{$\begin{array}{l}\text { Whole } \\
\text { wheat }\end{array}$} & \multirow{2}{*}{$\begin{array}{c}\text { Patent } \\
\text { flour }\end{array}$} \\
\hline & 1st & 2nd & $3 \mathrm{rd}$ & 4 th & & & \\
\hline $\begin{array}{l}\text { Fibre (per cent) } \\
\text { Ash (per cent) } \\
\text { Protein (per cent) } \\
\text { Iron (mgm./100 gm.) } \\
\text { Total P (mgm./100 gm.) } \\
\text { Phytate P (mgm./100 gm.) } \\
\text { Phytate P/total P } \\
\mathrm{B}_{1} \text { (I.0./gm.) } \\
\text { Riboflavin ( } \mu \mathrm{gm} . / \mathrm{gm} .) \\
\text { Nicotinic acid ( } \mathrm{gmm} . / \mathrm{gm} .) \\
\text { Theoretical per cent by weight of wheat }\end{array}$ & $\begin{array}{c}\overrightarrow{2 \cdot 1} \\
13 \cdot 6 \\
6 \cdot 4 \\
490 \\
371 \\
0 \cdot 78 \\
1 \cdot 4 \\
1 \cdot 9 \\
77 \\
0 \cdot 89\end{array}$ & $\begin{array}{c}\overline{3 \cdot 9} \\
14 \cdot 3 \\
11 \cdot 3 \\
937 \\
805 \\
0 \cdot 86 \\
1 \cdot 8 \\
1 \cdot 5 \\
148 \\
0 \cdot 39\end{array}$ & $\begin{array}{c}\overline{5} \cdot 9 \\
15 \cdot 6 \\
16 \cdot 0 \\
1440 \\
1245 \\
0 \cdot 86 \\
2 \cdot 1 \\
1 \cdot 7 \\
240 \\
0 \cdot 34\end{array}$ & $\begin{array}{c}\overline{7} \cdot 7 \\
16 \cdot 2 \\
21 \cdot 4 \\
1850 \\
1593 \\
0 \cdot 88 \\
2 \cdot 3 \\
2 \cdot 0 \\
393 \\
0 \cdot 43\end{array}$ & $\begin{array}{c}11 \cdot 5 \\
6 \cdot 54 \\
11 \cdot 4 \\
12 \cdot 4 \\
1494 \\
1280 \\
0 \cdot 86 \\
1 \cdot 6 \\
5 \cdot 0 \\
250 \\
12 \cdot 5\end{array}$ & $\begin{array}{c}2 \cdot 0 \\
1 \cdot 49 \\
8 \cdot 9 \\
2 \cdot 95 \\
311 \\
213 \\
0 \cdot 68 \\
1 \cdot 03 \\
1 \cdot 55 \\
42 \\
100\end{array}$ & $\begin{aligned} & \overline{0} \cdot 39 \\
& 8 \cdot 1 \\
& 0 \cdot 54 \\
& 59 \\
&<10 \\
&<0 \cdot 17 \\
& 0 \cdot 13 \\
& 0 \cdot 4 \\
& 5 \\
& 11\end{aligned}$ \\
\hline
\end{tabular}

